\title{
QTL analysis for Malt Quality in DH Lines of Barley (Steptoe $\times$ Morex) grown in sub-tropical zone of Iran
}

\author{
Mohammad Bahman Sadeghi ${ }^{{ }^{*}}$, Wakil Ahmad Sarhadi ${ }^{2}$, Seyed Ali Peighambari ${ }^{3}$, \\ Mohammad Reza Naghavi ${ }^{3}$, Ahmad Kalbasi Ashtari ${ }^{4}$ \\ 1 * Department of Biotechnology and Seed Production, Faculty of Agriculture, Kabul University, Afghanistan and Department of Agronomy \\ and Plant breeding, Faculty of Agricultural Science and Engineering, University of Tehran, Karaj, Iran \\ ${ }^{2}$ Department of Agronomy, Faculty of Agriculture, Kabul University, Afghanistan \\ ${ }^{3}$ Department of Agronomy and Plant breeding, Faculty of Agricultural Science and Engineering, University of Tehran, Karaj, Iran \\ ${ }^{4}$ Department of Food Science and Technology, Faculty of Agricultural Technology and Engineering, University of Tehran, Karaj, Iran
}

\section{A R T I C L E I N F O}

\section{Article history:}

Received 20 November 2013

Accepted 20 December 2013

Available online, ISSN: 2148-127X

\section{Keywords:}

Doubled haploid

Malting quality

Morex

Steptoe

Protein content

QTL.

\begin{abstract}
A B S T R A C T
In order to study the quantitative variability of malting quality-related traits and to determine the genomic locations which control these traits, an experiment was conducted using one hundred fifty double haploid (DH) lines of barley and their two parents 'Steptoe' \& 'Morex'. Protein content (\%) was measured using Kjeldahl method, diastatic power calculated with Lintner formula, Malt extract was measured for each by special weight achieved and based on Malt Berix Charts. Transgressive segregation in both directions was observed for all traits. Genetic map is fairly saturated and comprising 327 RFLP markers with a total length of $1226.3 \mathrm{cM}$ with an average marker spacing of $3.75 \mathrm{cM}$. Seventeen QTLs by $\mathrm{LOD} \geq 2(\mathrm{LRS} \geq 9.21)$ controlling different studied traits were identified for all studied traits. Total phenotypic variance explained by these QTLs varies from 23.2 to $45.05 \%$. Highest LOD scores were obtained for QTL's controlling diastatic power (Qdip3Ha) on chromosome 3H, and lowest LOD scores were obtained for QTL's controlling seed yield per plant $(Q \operatorname{syp} 1 \mathrm{Hb})$ on chromosome $1 \mathrm{H}$. Therefore gain through marker-assisted selection (MAS) in this population would be limited and some of the "Steptoex Morex" population was developed with the intention of isolating and advancing barley lines for release to the malting quality.
\end{abstract}

${ }^{*}$ Corresponding Author:

E-mail: mbsadeghi@alumni.ut.ac.ir

\section{Introduction}

Main purpose of barley modification programs is preparation of $F_{1}$ hybrid types and double haploids (Chen and Hayes, 1989) with high grain yield and malt quality. Malt performance is determined by grain yield per surface unit and amount of malt extraction from grain production (Bamforth and Martin, 1981; Singh et al, 1993; Hayes and Iyambo, 1994). The underlying philosophy in use of markers information for QTL mapping and study is very simple. By crossing two lines inbred, linkage disequilibrium is created between gene locations which are different in them and consequently marker's gene locations and the linked QTLs to them are dispersed. Linkage disequilibrium means that two linked gene locations tends to remain linked and consequently their scattering will not be independent from one another and this is the fundament of genes mapping. In these methods, linked disequilibrium between genomic places is used to identify and localize QTLs. According to genotypic data, linkage map is prepared and then using such models as Single Marker Analysis, Interval Mapping, Composite Interval Mapping (CIM), mixed models, etc., the assumed QTLs within area of a marker or between two neighboring markers are localized and share of each QTL in determining phenotypic variance is specified. To make sure of perfect linkage between marker and QTL without an error of first type or its reduction in selection by means of the marker, several meiotic cycles are required. Different pieces of research have used QTL analysis for 
different criteria of Steptoe and Morex population such as malt quality (Ayoub et al., 2003), yield and its components (Peighambari et al., 2005), seed quality (Abdel-Haleem, 2004; Han et al., 1997; See et al., 2002), forage quality (Taleei et al., 2009; Siyahsar and Narouei 2010) and environmental adaptation (Mickelson et al., 2003; Kolatsou and Palmer, 2004 ; Malosetti et al., 2004; Mayo, 2004). In this issue we will consider precence or nonprecence of malting quality QTLs for 150 Steptoe $\times$ Morex DH lines in environment of Iran (Karaj).

\section{Materials and Methods}

One hundred-fifty doubled haploid barley lines from the barley 'Steptoe' and 'Morex' cross population, receipted from Toulous University, France, were used in this study. Steptoe is six-row, high yield, sensitive to drought, long seed dormancy, leaf bacterial tape disease, and forage. Morex is six-row, resistance to drought, with high malt quality and amylase, short seed dormancy, resistant to leaf bacterial tape disease. The seeds were sown on agricultural year 2010-2011 under lattice design as $8 \times 9$ rectangular with three repetitions in research farm of Agriculture Faculty (Karaj), Tehran University (geographical longitude of $50^{\circ}$ and 58' east, geographical latitude of $35^{\circ}$ and $49^{\prime}$ north, and height from sea level $1321 \mathrm{~m})$. Fifty seeds in $2.5 \mathrm{~m}$ lines with atmospheric distance and stacks of $25 \mathrm{~cm}$ cultivated. Irrigation was done according to custom of the location from cultivation time to harvest. The under study attributes were divided into two agronomic and physicochemical groups. Agronomic attributes were Heading (Days), Total growth duration (Days), Flag leaf length $(\mathrm{cm})$, Spike length $(\mathrm{cm})$, Height (cm), Seed per spike, 1000- seed weight (gram), Tillers per plant, Seed yield per plant (gram). To measure agronomic attributes of Height $(\mathrm{cm})$, Seeds per spike, Spike length $(\mathrm{cm})$, Flag leaf length $(\mathrm{cm})$ and Seed yield per plant (gram) by observing margin of 10 shrubs were randomly selected in each patch and their mean was used. Physicochemical attributes of malt were: Protein content

$(\%)$, Diastatic power ( $L^{\circ}$ ), Alpha amylase activity, Malt extract $(\%)$. Two grams seed obtained in each line and for measuring percentage of grain protein, the fully automatic Kjeldahl device was used. Calculation of Diastatic power was performed based on Lintner unit ( $L^{\circ}$ ) with the equation 2000/xy in which, $x$ is the used enzyme extract and $y$ amount of the starch transformed into titration. Enzyme of alpha amylase was used as catalyst during malt baking for hydrolysis of starch into sugar. A specific volume of sample malt extract (wort) was poured into the calibrated cup and weighed. From division of the obtained weight on volume, specific weight was obtained and using specific table, amount of breaks or percentage of solid materials, amount of malt extract in each genotype was specified (Schmitt and Budde, 2007; Jones, 2005). Variance analysis was performed using SAS software. Simple statistical statistics include mean, range of changes, standard deviation, percentage of changes coefficient, phenotypic and genetic diversity coefficient, heritability, genetic progress and genetic yield (performance) for 5\% selection of 13 attributes regarding quantity and quality of malt barley of 150 double haploid lines and their parents (Steptoe and Morex) was calculated using univariate method and SAS software. Heritability was calculated using the formula $\mathrm{h}^{2}=\frac{V_{G}}{V_{G}+V_{E}}$ (Therrien, 2003), where $\mathrm{V}_{\mathrm{G}}$ and $\mathrm{V}_{\mathrm{E}}$ are genetic variance and environmental variance, respectively (environmental variance is the error within the block). Since additive variance is twice in double haploid lines, the calculated heritability amount should be halved $\left(\mathrm{V}_{\mathrm{A}}=1 / 2 \sigma_{\mathrm{DH}}^{2}\right)$ (Singh et al, 1993; Falconer, 1982). Genetic gain to positive $\left(G_{p}\right)$ and genetic gain to negative $\left(G_{N}\right)$ of attributes was calculated using the formulas $\mathrm{GG}_{\mathrm{p}}=\mathrm{B}_{\mathrm{DH}}-$ $\mathrm{B}_{\mathrm{p}}$ and $\mathrm{GG}_{\mathrm{N}}=\mathrm{W}_{\mathrm{DH}}-\mathrm{W}_{\mathrm{p}}$, that $\mathrm{B}_{\mathrm{DH}}$ and $\mathrm{W}_{\mathrm{DH}}$ are the best and the worst double haploid line, and $\mathrm{B}_{\mathrm{p}}$ and $\mathrm{W}_{\mathrm{p}}$ are the best and the worst parents, respectively. Phenotypic and genotypic diversity coefficients were calculated using the formulas $\mathrm{PCV}=\left(\sigma_{\mathrm{p}} / \overline{\mathrm{X}}\right) 100$ and $\mathrm{GCV}=\left(\sigma_{\mathrm{g}} / \overline{\mathrm{X}}\right) 100$ (Johnson et al, 1955), where $\sigma_{\mathrm{p}}$ and $\sigma_{\mathrm{g}}$ are phenotypic and genotypic standard deviation and $\frac{\bar{X}}{\mathrm{X}}$ is society mean. Genetic performance for the selection $5 \%$ was calculated using $\mathrm{G}_{\mathrm{c}}=\mathrm{Kh}^{2} \sigma_{\mathrm{p}}$ (Johnson et al, 1955), where $\mathrm{K}$ is the standardized selection differential (for selection 5\%, the constant value $\mathrm{K}$ is equal to 2.065), $\sigma_{\mathrm{p}}$ phenotypic standard deviation, and $\mathrm{h}^{2}$ attribute's heritability.

Population's barley genetic map resulting from Steptoe and Morex crossing was prepared by North American Barley Genome Mapping Project (NABGMP) (Kleinhofs et al, 1993; Hayes, 1993). This relatively saturated map is consisted of 327 RFLP markers to the length of 1226.3 and average distance of $3.75 \mathrm{cM}$ and is prepared by Kosambi plotting function (Kosambi, 1944; Hayes, 1993; Kleinhofs et al, 1993; Beecher et al, 2001; Borém et al, 1999; Han and Ullrich, 1994; Han et al, 1997). This map was retrieved from http://barleygenomics.wsu.edu/. First, from the main map data regarding 150 lines, a new map data using 20 primers used for 150 lines in this research was created and QTL analysis was performed based on new map data and its genetic map. In this map, 7 linkage groups were identified. QTL analysis was done by WinQTL cartographer software version 2.5 (Wang et al, 2007), mean total experiment was performed for each attribute individually. For determining QTLs and estimation of their effect (increasing effects), Composite Interval Mapping (CIM) was used (Jansen and Stam, 1994; Zeng, 1994). To determine significant threshold (5\%) of peaks genomes related to QTLs, data permutation test (Churchill and Doerage, 1994; Doerage and Churchill, 1996) was used. If there is a fall to the amount of $\mathrm{LOD} \geq 2$ (LRS $\geq 9.21$ ) between two neighboring peaks, two separate QTL was considered (Kim and Rieseberg, 1999). Percentage of justified phenotypic variance was determined by each QTL. LOD peaks showed QTL position and QTL effects were obtained on that point. Finally, chromosomes diagram and QTL position were drawn by the Join map 3.0 software.

\section{Results}

Mean squares of change sources in variance analysis of 150 barley lines along with parents of agronomic and physicochemical attributed related to malt quantity and quality in normal condition of Karaj are presented in Table 1. The difference between genotypes for the attributes Seeds per spike and Alpha amylase activity 
under study was significant at $1 \%$ probability and for the attributes Spike length, Height, 1000- seed weight, Tillers per plant and Protein content $(\%)$ was significant at $5 \%$ probability level. Therefore, it is inferred that there was a significant diversity between lines for various attributes. Additive and environmental variance was calculated for all the attributes (Table 1).

The difference between parents which is one of criteria of increasing effect for the attributes in question was significant for Heading, Seed per spike, Protein content $(\%)$, Diastatic power and Alpha amylase activity at $1 \%$ probability and for the attribute Malt extract at 5\% probability. The difference between mean lines and mean parents for the attribute Height $(\mathrm{cm})$ at $1 \%$ probability and for Heading, Seed per spike, 1000- seed weight and Seed yield per plant at $5 \%$ probability was significant (Table 2). Heritability explains to what extent the diversity is due to genetic factors (Therrien, 2003). Average distance (interval) between two markers has shown $1.26 \mathrm{cM}$ reduction at application of SRR specific primers and mapping by suitable software (Joinmap 3.0). In fact precision degree has increased (Table 3). The QTLs of 13 agronomic and physicochemical attributes related to malt of 150 double haploid barley lines obtained from crossing of Steptoe and Morex, LOD, increasing effects, confidence interval of $95 \%$ and $\mathrm{R}^{2}$ value for each attribute are presented in Table 4. On chromosome 5H, no QTL was observed. Highest LOD scores were obtained for QTL's controlling diastatic power (Qdip3Ha) on chromosome $3 \mathrm{H}$, and lowest LOD scores were obtained for QTL's controlling seed yield per plant (QsyplHb) on chromosome $1 \mathrm{H}$. The obtained results from this research indicate that the discovered QTLs controlling grain yield on chromosomes $4 \mathrm{H}$ and $1 \mathrm{H}$ are consistent with research of Kandmir et al (2000) on chromosome $1 \mathrm{H}$ and Hayes et al (1997) on chromosomes $1 \mathrm{H}, 2 \mathrm{H}$ and $3 \mathrm{H}$. The discovered QTL controlling the attribute Height on chromosome $2 \mathrm{H}$ is consistent with research of Kandmir et al (2000) on chromosome $3 \mathrm{H}$ and Hayes and Iyambo (1994) on chromosomes $2 \mathrm{H}, 3 \mathrm{H}$ and $4 \mathrm{H}$. The discovered QTLs controlling the attribute Protein content (\%) on chromosome $4 \mathrm{H}, 1 \mathrm{H}$ and $6 \mathrm{H}$ are consistent with research of Hayes and Iyambo (1994) on chromosomes $2 \mathrm{H}$ and 4H. QTLs of malt in the 7 chromosomes present in barley have been determined, but the most important of them are in centromer areas of $5 \mathrm{H}, 2 \mathrm{H}, 4 \mathrm{H}, 6 \mathrm{H}$ and $5 \mathrm{H}$ and in long arm areas of chromosomes $1 \mathrm{H}$ and $5 \mathrm{H}$ (Abdel-Haleem et al, 2004; Peighambari et al, 2005; Siyahsar and Narouei, 2010, Taleei et al, 2009).The discovered QTL controlling the attribute Diastatic power on chromosome $3 \mathrm{H}$ and amount of Malt extract on chromosome $7 \mathrm{H}$ and Alpha amylase activity on chromosomes $3 \mathrm{H}$ and $4 \mathrm{H}$ is consistent with results obtained by Hayes et al (1997), Mather et al (1997) and Han et al (1997). Hayes and Iyambo (1994) found that the genes Amy2 and Bmy2 have role in coding malt quality enzymes in centromer areas of chromosomes $7 \mathrm{H}$ and $2 \mathrm{H}$ and the gene $\mathrm{Glbl}$ in coding malt quality enzymes in long arm of chromosome $1 \mathrm{H}$ for $\mathrm{DH}$ lines derived of Steptoe and Morex.

Table 1. Analyze of variance for malting quality and quantity in DH lines of barley (Steptoe \& Morex) in Karaj (Iran), in 2010.

\begin{tabular}{|c|c|c|c|c|c|c|c|c|c|c|c|c|c|c|}
\hline \multicolumn{15}{|c|}{ Mean of squares } \\
\hline S.O.V & DF & $\begin{array}{c}\text { Heading } \\
\text { (Days) }\end{array}$ & $\begin{array}{c}\text { Total } \\
\text { growth } \\
\text { duration } \\
\text { (Days) }\end{array}$ & $\begin{array}{c}\text { Flag } \\
\text { leaf } \\
\text { length } \\
(\mathrm{cm})\end{array}$ & $\begin{array}{l}\text { Spike } \\
\text { length } \\
(\mathrm{cm})\end{array}$ & $\begin{array}{l}\text { Height } \\
(\mathrm{cm})\end{array}$ & $\begin{array}{l}\text { Seeds } \\
\text { per } \\
\text { spike }\end{array}$ & $\begin{array}{c}1000- \\
\text { seed } \\
\text { weight } \\
\text { (gram) }\end{array}$ & $\begin{array}{c}\text { Tillers } \\
\text { per } \\
\text { plant }\end{array}$ & $\begin{array}{c}\text { Seed } \\
\text { yield per } \\
\text { plant } \\
\text { (gram) }\end{array}$ & $\begin{array}{c}\text { Protein } \\
\text { content } \\
(\%)\end{array}$ & $\begin{array}{c}\text { Diastatic } \\
\text { power } \\
\left(L^{0}\right)\end{array}$ & $\begin{array}{l}\text { Alpha } \\
\text { amylase } \\
\text { activity }\end{array}$ & $\begin{array}{c}\text { Malt } \\
\text { extract } \\
(\%)\end{array}$ \\
\hline Replication & 2 & 80.7 & 18.92 & 0.57 & 0.81 & 28.77 & 5.69 & 23.85 & 8.61 & 37.43 & 3.78 & 4883.97 & 94.23 & 22.68 \\
\hline $\begin{array}{l}\text { Treatment } \\
\text { Adjusted }\end{array}$ & 71 & $14.11^{\mathrm{ns}}$ & $7.28^{\mathrm{ns}}$ & $2.23^{\mathrm{ns}}$ & $2.01^{*}$ & $106.15^{*}$ & $23.79^{* * *}$ & $6.02^{*}$ & $1.91^{*}$ & $10.31^{\mathrm{ns}}$ & $0.89^{*}$ & $215.83^{\mathrm{ns}}$ & $11.89^{* *}$ & $2.47^{\mathrm{ns}}$ \\
\hline $\begin{array}{l}\text { Blocks within } \\
\text { Reps (adj.) }\end{array}$ & 24 & 22.36 & 7.49 & 5.4 & 1.21 & 99.01 & 45.44 & 9.8 & 2.2 & 21.51 & 5.9 & 476.81 & 15.92 & 9.26 \\
\hline $\begin{array}{l}\text { Error Inter a } \\
\text { block }\end{array}$ & 118 & 14.53 & 6.14 & 3.41 & 1.05 & 77.96 & 14.69 & 4.36 & 0.99 & 9.4 & 1.23 & 225.27 & 9.02 & 2.06 \\
\hline RCB Design & 142 & 15.85 & 6.37 & 3.74 & 1.08 & 81.52 & 19.89 & 5.28 & 1.2 & 11.44 & 2.02 & 267.79 & 10.19 & 3.28 \\
\hline $\begin{array}{l}\text { Additive } \\
\text { Variance }\end{array}$ & $\left(\mathrm{V}_{\mathrm{A}}\right)$ & 6.19 & 2.34 & 1.08 & 0.53 & 22.08 & 6.58 & 2.35 & 0.28 & 2.54 & 0.62 & 147.57 & 2.02 & 1.02 \\
\hline $\begin{array}{l}\text { Environment } \\
\text { Variance }\end{array}$ & $\left(V_{E}\right)$ & 14.53 & 6.14 & 3.41 & 1.05 & 77.96 & 14.69 & 4.36 & 0.99 & 9.4 & 1.23 & 225.27 & 9.02 & 2.06 \\
\hline
\end{tabular}

ns: No Significant ${ }^{*}:$ Significant (5\%) ${ }^{* *}$ : Highly Significant (1\%) 
Table 2. Simple statistics include GGN: Genetic gain to negative; GGP: Genetic gain to positive; GCV(\%) : Genotypic Coefficient of variation(\%); PCV(\%) : Phenotypic Coefficient of variation(\%)

\begin{tabular}{|c|c|c|c|c|c|c|c|c|c|c|c|c|c|}
\hline & $\begin{array}{l}\text { Heading } \\
\text { (Days) }\end{array}$ & $\begin{array}{c}\text { Total } \\
\text { growth } \\
\text { duration } \\
\text { (Days) }\end{array}$ & $\begin{array}{c}\text { Flag } \\
\text { leaf } \\
\text { length } \\
(\mathrm{cm})\end{array}$ & $\begin{array}{l}\text { Spike } \\
\text { length } \\
(\mathrm{cm})\end{array}$ & $\begin{array}{l}\text { Height } \\
(\mathrm{cm})\end{array}$ & $\begin{array}{l}\text { Seeds } \\
\text { per } \\
\text { spike }\end{array}$ & $\begin{array}{c}1000- \\
\text { seed } \\
\text { weight } \\
\text { (gram) }\end{array}$ & $\begin{array}{c}\text { Tillers } \\
\text { per } \\
\text { plant }\end{array}$ & $\begin{array}{c}\text { Seed } \\
\text { yield per } \\
\text { plant } \\
\text { (gram) }\end{array}$ & $\begin{array}{c}\text { Protein } \\
\text { content } \\
(\%)\end{array}$ & $\begin{array}{c}\text { Diastatic } \\
\text { power } \\
\left(L^{0}\right)\end{array}$ & $\begin{array}{c}\text { Alpha } \\
\text { amylase } \\
\text { activity }\end{array}$ & $\begin{array}{c}\text { Malt } \\
\text { extract } \\
(\%)\end{array}$ \\
\hline Steptoe (P1) & 171.23 & 205.67 & 13.3 & 8.13 & 76.4 & 53.37 & 35.47 & 5.87 & 8.75 & 14.2 & 63.2 & 23.7 & 74.4 \\
\hline Morex $\left(\mathrm{P}_{2}\right)$ & 183.24 & 202.76 & 12.47 & 8.5 & 74.53 & 62.87 & 36.07 & 4.78 & 9.97 & 9.7 & 115.7 & 32.34 & 77.4 \\
\hline$P_{1-} P_{2}$ & $-12.01 * *$ & $2.91^{\mathrm{ns}}$ & $0.82^{\mathrm{ns}}$ & $-0.27^{\mathrm{ns}}$ & $1.87^{\mathrm{ns}}$ & $-9.5 * *$ & $-0.6^{\mathrm{ns}}$ & $1.09^{\mathrm{ns}}$ & $-1.21^{\mathrm{ns}}$ & $4.5^{* *}$ & $-51.5 * *$ & $-8.64 * *$ & $-3 *$ \\
\hline $\bar{x}_{P}=\left(P_{1}+P_{2}\right) / 2$ & 177.22 & 204.21 & 12.88 & 8.31 & 75.96 & 58.12 & 35.77 & 5.32 & 9.36 & 11.95 & 89.45 & 28.02 & 75.9 \\
\hline Worst DHs & 186.67 & 207.97 & 11.6 & 7.53 & 100.7 & 55.58 & 35.37 & 5.32 & 10.47 & 13.96 & 71.53 & 22.97 & 71.52 \\
\hline Best DHs & 176.33 & 109.9 & 15.16 & 10.03 & 74.06 & 69.87 & 40.09 & 8.23 & 19.72 & 11.28 & 110.51 & 32.03 & 75.95 \\
\hline Range & 20 & 14 & 9.3 & 4.6 & 47 & 21.1 & 12.13 & 5 & 15.01 & 7.6 & 94 & 19.9 & 8.9 \\
\hline $\bar{x}_{D H s}$ & 182.48 & 203.28 & 13.3 & 8.65 & 88.95 & 62.4 & 37.48 & 6.68 & 14.51 & 12.5 & 90.45 & 27.84 & 74.19 \\
\hline $\mathrm{SD}_{\mathrm{DHs}}$ & 3.81 & 1.72 & 1.84 & 1.02 & 8.82 & 3.83 & 2.08 & 0.99 & 3.06 & 1.1 & 15 & 3 & 1.43 \\
\hline $\mathrm{CV}_{\mathrm{DHs}}$ & 2.08 & 1.23 & 8.32 & 11.98 & 10.1 & 6.49 & 5.83 & 15.63 & 9.12 & 6.48 & 7.33 & 11.18 & 2.06 \\
\hline $\bar{x}_{D H s}-\bar{x}_{P}$ & $5.36 *$ & $-0.92^{\mathrm{ns}}$ & $0.41^{\mathrm{ns}}$ & $0.34^{\mathrm{ns}}$ & $12.99 * *$ & $4.28 *$ & $1.71 *$ & $1.36^{\mathrm{ns}}$ & $5.15 *$ & $0.55^{\mathrm{ns}}$ & $1.01^{\mathrm{ns}}$ & $-0.18^{\mathrm{ns}}$ & $-1.71^{\mathrm{ns}}$ \\
\hline $\mathrm{GG}_{\mathrm{N}}=\mathrm{W}_{\mathrm{DH}^{-}}-\mathrm{W}_{\mathrm{P}}$ & $3.43 *$ & $2.2^{\mathrm{ns}}$ & $-0.87^{\mathrm{ns}}$ & $-0.6^{\mathrm{ns}}$ & $24.3 *$ & $2.21^{\mathrm{ns}}$ & $-0.2^{\mathrm{ns}}$ & $0.54^{\mathrm{ns}}$ & $1.72^{\mathrm{ns}}$ & $-0.24^{\mathrm{ns}}$ & $8.33^{\mathrm{ns}}$ & $-0.72^{\mathrm{ns}}$ & $-2.88 *$ \\
\hline $\mathrm{GG}_{\mathrm{P}}=\mathrm{B}_{\mathrm{DH}}-\mathrm{B}_{\mathrm{P}}$ & $-6.91 * *$ & $-3.76^{\mathrm{ns}}$ & $1.86^{*}$ & $1.53 *$ & $-0.47^{\mathrm{ns}}$ & $16.5^{* *}$ & $4.02 *$ & $2.26^{\mathrm{ns}}$ & $9.75 *$ & $1.58 *$ & $-5.19^{\mathrm{ns}}$ & $-0.31^{\mathrm{ns}}$ & $-1.45^{\mathrm{ns}}$ \\
\hline $\mathrm{GCV}(\%)$ & 1.7 & 0.99 & 9.67 & 11.32 & 8.1 & 5.32 & 4.78 & 12.79 & 18.15 & 7.79 & 14.21 & 9.16 & 1.69 \\
\hline $\operatorname{PCV}(\%)$ & 2.69 & 1.57 & 17.91 & 15.29 & 12.81 & 8.13 & 7.34 & 19.63 & 27.85 & 11.81 & 21.84 & 14.15 & 2.57 \\
\hline $\mathrm{GC}_{5 \%}$ & 4.05 & 2.62 & 1.96 & 1.08 & 9.38 & 4.48 & 2.4 & 1.14 & 3.53 & 1.31 & 17.22 & 3.4 & 1.5 \\
\hline $\mathrm{h}^{2}$ & 0.39 & 0.38 & 0.42 & 0.39 & 0.39 & 0.41 & 0.42 & 0.41 & 0.42 & 0.43 & 0.42 & 0.41 & 0.43 \\
\hline
\end{tabular}

ns: No Significant *: Significant (5\%) **: Highly Significant (1\%)

Table 3. Markers distribution in linkage map groups of double haploid barley lines along with parents (Steptoe and Morex) in new map

\begin{tabular}{c|ccc}
\hline $\begin{array}{c}\text { Linkage } \\
\text { group }\end{array}$ & $\begin{array}{c}\text { Number of } \\
\text { Markers }\end{array}$ & $\begin{array}{c}\text { Chromosome } \\
\text { length }\end{array}$ & $\begin{array}{c}\text { Average distance between two } \\
\text { markers }(\mathrm{cm})\end{array}$ \\
\hline$(5) 1 \mathrm{H}^{*}$ & 23 & 61 & 2.65 \\
$(2) 2 \mathrm{H}$ & 39 & 106 & 2.71 \\
$(3) 3 \mathrm{H}$ & 34 & 99 & 2.91 \\
$(4) 4 \mathrm{H}$ & 32 & 98 & 3.06 \\
$(7) 5 \mathrm{H}$ & 6 & 9 & 1.50 \\
$(6) 6 \mathrm{H}$ & 16 & 44 & 2.75 \\
$(1) 7 \mathrm{H}$ & 63 & 120 & 1.90 \\
Total & 190 & 537 & 2.49 \\
\hline
\end{tabular}

* Numbers within parentheses are chromosomes former naming and the numbers with letter $\mathrm{H}$ are chromosomes new naming

Table 4. Identified QTLs; rate of LOD; effectives of Add. and rate of R2 (Proportion of phenotypic variance explained) for each trait.

\begin{tabular}{|c|c|c|c|c|c|c|c|c|}
\hline Traits & QTL & $\begin{array}{c}\text { Chromosome } \\
\text { name }\end{array}$ & $\begin{array}{c}\text { The nearest } \\
\text { marker }\end{array}$ & $\begin{array}{c}\text { QTL } \\
\text { position }\end{array}$ & $\begin{array}{c}\text { Confidence } \\
\text { interval } \\
(\% 95) \text { of } \\
\text { QTL }\end{array}$ & LOD & $\begin{array}{c}\text { Allelic } \\
\text { effectives } \\
\text { (Additive) }\end{array}$ & $\mathrm{R} 2$ \\
\hline X2: Total growth duration (Days) & Qmat4Ha & $4 \mathrm{H}$ & $\mathrm{ABC} 257$ & 79 & $78-81$ & 2.4 & 0.568 & 31.16 \\
\hline \multirow[t]{2}{*}{ X3 : Flag leaf length $(\mathrm{cm})$} & Qfll7Ha & $7 \mathrm{H}$ & TLM3 & 70 & $69-71$ & 2.5 & 0.3 & 36.48 \\
\hline & Qfll2Hb & $2 \mathrm{H}$ & $\mathrm{dRcs} 1$ & 18 & $17-19$ & 2.8 & 0.29 & 38.55 \\
\hline X4 : Spike length $(\mathrm{cm})$ & Qspl4Ha & $4 \mathrm{H}$ & ABG063 & 30 & $28-32$ & 3.1 & 0.23 & 38.95 \\
\hline X5 : Height $(\mathrm{cm})$ & Qhei2Ha & $2 \mathrm{H}$ & $\mathrm{ABC} 158$ & 25 & $23-27$ & 3.3 & -2.39 & 37.32 \\
\hline X6 : Seeds per spike & Qsps7Ha & $7 \mathrm{H}$ & ABG008 & 106 & $105-108$ & 3.1 & -1.1 & 37.24 \\
\hline X7:1000-seedweight(gram) & Qtws3Ha & $3 \mathrm{H}$ & MWG077 & 7 & $6-9$ & 2.6 & 0.39 & 33.75 \\
\hline $\mathrm{X} 8$ : Tillers per plant & Qtpp7Ha & $7 \mathrm{H}$ & WG110 & 68 & $67-69$ & 3.6 & -0.24 & 34.15 \\
\hline \multirow[t]{2}{*}{ X9 :Seed yield per plant (gram) } & Qsyp4Ha & $4 \mathrm{H}$ & ABG702 & 89 & $88-91$ & 2.3 & -0.66 & 36.63 \\
\hline & Qsyp $1 \mathrm{Hb}$ & $1 \mathrm{H}$ & Nar7 & 55 & $54-57$ & 2.1 & 0.29 & 23.2 \\
\hline \multirow{3}{*}{ X10 : Protein content $(\%)$} & Qprp4Ha & $4 \mathrm{H}$ & MWG837 & 11 & $9-13$ & 2.5 & -0.22 & 45.05 \\
\hline & Qprp1Hb & $1 \mathrm{H}$ & ASE18 & 0 & $0-1$ & 2.4 & 0.23 & 45.05 \\
\hline & Qprp6Hc & $6 \mathrm{H}$ & MWGB51C & 40 & $39-41$ & 2.8 & 0.29 & 45.02 \\
\hline \multirow{3}{*}{$\begin{array}{l}\text { X11 : Diastatic power }\left(L^{0}\right) \\
\text { X12: Alpha amylase activity }\end{array}$} & Qdip3Ha & $3 \mathrm{H}$ & KFP195 & 31 & $30-33$ & 4.9 & -6.64 & 37.82 \\
\hline & Qala3Ha & $3 \mathrm{H}$ & CDO669 & 9 & $7-11$ & 2.3 & 0.6 & 28.75 \\
\hline & Qala4Hb & $4 \mathrm{H}$ & ABG702 & 89 & $88-91$ & 2.3 & -0.69 & 32.94 \\
\hline X13 : Malt extract (\%) & Qmex7Ha & $7 \mathrm{H}$ & ADC 1670 & 75 & $74-77$ & 3.2 & 0.34 & 36.63 \\
\hline
\end{tabular}




\section{Discussion}

Positive and negative allelic effects related to QTLs justified the existing positive and negative correlations between the attributes. In other words, equisignal allelic effects result in positive correlation and allelic effect with varying signs result in negative correlation between attributes. Collocation of several QTLs is due to linkage between two genes or Pleiotropy effect of one gene. Pleiotropy simultaneously controls two or more attributes (attributes sub-components) and when one attribute is selected, this leads to simultaneous increase or decrease of correlated attributes. In Pleiotropy, correlation between attributes never breaks. QTLs collocation justifies correlation between attributes. Peighambari et al (2005) reported in this population of the QTLs controlling the attributes day to flowering, Heading, Total growth duration, Height, Spike length, Spike per plant, Seed per spike, 1000- seed weight, Protein content $(\%)$ and grain yield are stable in varying years and they can be used in selection by means of marker. Application of selection by means of marker for such attributes as performance and malt quality in this population has been shown (Ayoub et al, 2003). Thus, selection by means of marker for attributes in this population has the necessary efficiency. Although for agronomic and physicochemical attributes related to malt plenty of QTLs was determined and some of them had the necessary stability, but it seems that most of them in different experimental conditions have not the required stability and in some instances, their stability was low. Thus, outcome of selection by means of marker in this population will be limited, because environment has a significant role in phenotypic and genotypic demonstration of agronomic and physicochemical attributes related to malt and Steptoe $\times$ Morex population has not been constructed for modification and separation of superior lines for purpose of liberation for usual use. The purpose for construction of such population has been barley genome mapping. This study was among the few reports on QTL analysis. In this study, those attributes were identified which could be used in barley selection programs. In addition, the first data for description of genetic control of agronomic and physicochemical attributes related to malt were obtained in barley. In this study, in total, 17 QTLs with LOD higher than 2 were identified for agronomic and physicochemical attributes related malt and these QTLs can be used in selection by molecular markers (Figure 1). It should be noted that localization of the chromosomal areas controlling the under study attributes is only a beginning for a long way. In order to use these QTLs for improvement of agronomic types, a lot of complementary studies in different years, environments and genetic contexts are needed (Stuber et al, 1999). To use these QTLs in modification programs, they need to have tight link with appropriate markers. Codominant nature of RFLP markers and their specialty Locus have made these markers be an ideal tool for marker selection programs. In this study, many stable QTL have been found which had close link with one or more RFLP marker. Therefore, it can be said that by means of these markers QTL can be transferred to the desirable types and genotypes. Often, all the QTLs related to an attribute are not required to be identified. In fact, it has been even claimed that introducing a large number of alleles with slight effect into regression methods and models strongly reduces efficiency of these models (Bernardo, 2001).

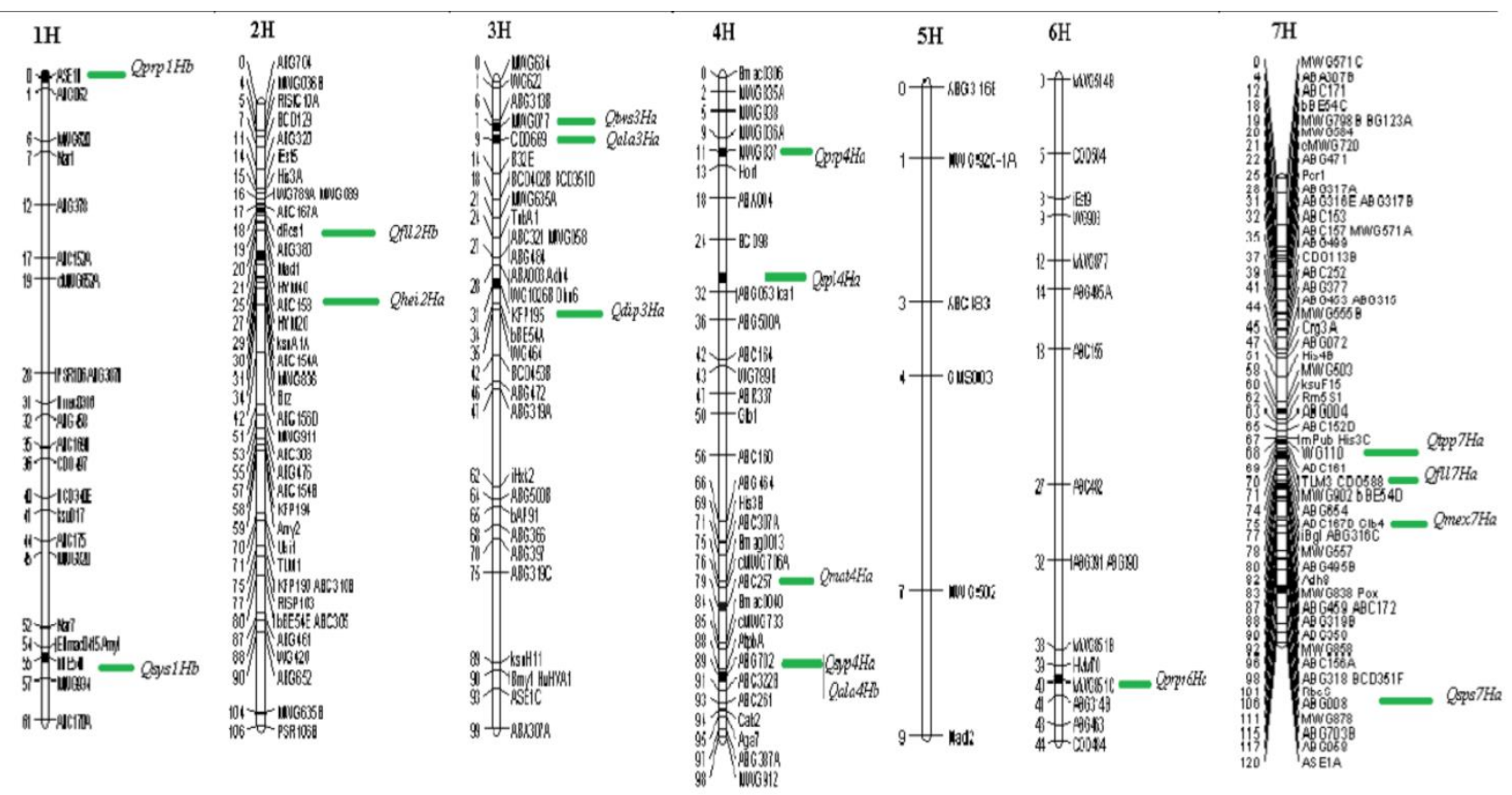

Figure 1. Linkage mapping of thirteen traits of agronomic and physicochemical malting quality in DH lines of barley $($ Steptoe $\times$ Morex ) 


\section{References}

Abdel-Haleem H, Giroux M, Talbert H, Bowman J, Kanazin V, Blake T. 2004. Identification of QTLs controlling the feed quality of barley. Plant \& Animal Genome XII Conf., Jan. 10-14, 2004, San Diego, CA. p.468.

Ayoub M, Armstrong E, Bridger G, Fortin MG, Mather DE. 2003. Marker-based selection in barley for a QTL region affecting alpha amylase activity of malt. Crop Sci. 43: 556561.

Bamforth CW, Martin HL. 1981. B-Glucan and B-glucan solubilase in malting and mashing. J. Inst. Brew. 87: 365371.

Beecher B, Smidansky ED, See D, Blake TK, Giroux MJ. 2001. Mapping and sequence analysis of barley hordoindolines. Theor. Appl. Genet.102: 833-840.

Bernardo R. 2001. What if we knew the genes for a quantitative trait in hybrid crops? Crop Sci. 41: 1-4.

Borém A, Mather DE, Rasmusson DC, Fulcher RG, Hayes P M. 1999. Mapping quantitative trait loci for starch granule traits in barley. J. Cereal Sci. 29: 153-160.

Chen F, Hayes PM. 1989. A comparison of Hordeum bulbosummediated haploid production efficiency in barley using in vitro floret and tiller culture. Theor. Appl. Genet. 77: 701704.

Churchill GA, Doerage RW. 1994. Empirical threshold values for quantitative trait mapping. Genetics. 138: 963-971.

Doerage RW, Churchill GA. 1996. Permutation tests for multiple loci affecting a quantitative character. Genetics . 142: 285-294.

Falconer DS. 1982. Introduction to quantitative genetics . Long man Inc. New York.

Guo B, Sleper DA, Nguyen HT, Arelli PR, Shannon JG. 2006 Quantitative trait loci underlying resistance to three soybean cyst nematode populations in soybean PI 404198A. Crop Sci. 46: 224-233.

Han F, Ullrich SE. 1994. Mapping of quantitative trait loci for malting quality traits in barley. Barley Genet. Newsl . 23: 84-97.

Han F, Romagosa I, Ullrich SE, Jones BL, Hayes PM, Wesenberg D. 1997. Molecular marker- assisted selection for malting quality traits in barley. Mol. Breed. 3: 427-437.

Hayes PM. 1993. Economic trait loci (quantitative trait lociQTL) analysis progress report. North American Barley Genome Mapping Project (NABGMP). Barley Genet. Newsl. 21: 30-31.

Hayes PM, Iyambo OE. 1994. Summary of QTL effects in the Steptoe \& Morex population, Barley Genet. Newsl. 23: 98143

Hayes PM, Cerono J, Witsenboer H, Kuiper M, Zabeau M, Sato K, Kleinhofs A, Kudrna D, Killian A, Saghai-Maroof M, Hoffman D. 1997. North American Barley Genome Mapping Project. Characterizing and exploiting genetic diversity and quantitative traits in barley (Hordeum vulgare) using AFLP markers. Journal of Agricultural Genomics 3 (2) (http://www.cabi-publishing.org/JAG).

$\mathrm{Hu}$ G, Burton C, Yang C. 2010. Efficient measurement of amylase content in cereal grains J. Cereal Sci. 51: 35-40.

Jansen RC, Stam P. 1994. High resolution of quantitative traits into multiple loci via interval mapping. Genetics. 136: $1447-1455$

Johnson HW, Robinson HF, Comestock RE. 1955. Estimations of genetic and environmental riability in soybean. Agron. J. 47: 314-318

Jones BL, Budde AD. 2005. How various malt endoproteinase classes affect wort soluble protein levels. Journal of Cereal Science 41: 95-106.

Jones BL. 2005. Review Endoproteases of barley and malt. Journal of Cereal Science 42.pp 139-156.
Kandemir N, Kudrna DA, Ullrich SE, Kleninhofs A. 2000. Molecular marker assisted genetic analysis of head shuttering in six-rowed barley. Thero. Appl . Genet . 101: 203-210.

Kim SC, Rieseberg LH. 1999 Genetic architecture of species differences in annual sunflowers implication for adaptive trait introgression. Genetics. 153: 965-977.

Kleinhofs A, Kilian A, Saghai Maroof MA, Biyashev RM, Hayes P, Chen FQ, Lspitan N, Fenwick A, Blake TK, Kanazin V, Ananiev E, Dahleen L, Kurdna D, Bollinger J, Knapp SJ, Liu B, Sorrells M, Heun M, Franckowiak JD, Hoffman D, Skadsen R, Stefffenson BJ. 1993. A molecular, isozymes, and morphological map of the barley (Hordeum vulgare ) genome. Theor. Appl. Genet. 86: 705-712.

Kolatsou M, Palmer GH. 2004. Relation between flour turbidity, malting and endosperm structure. J. Instit. Brew. 110: 193199.

Kosambi DD. 1944. The estimation of a map distance from recombination values. Ann. Eug. 12: 172-175.

Malosetti M, Voltas J, Romagosa I, Ullrich SE, Eeuwijk FA. 2004. Mixed models including environmental covariables for studying QTL by environment interaction. Euphytica 137: $139-145$

Mather DE, Tinker NA, LaBerge DE, Edney M, Jones BL, Rossnagle BG, Legge WG, Briggs KG, Irvine RB, Falk DE, Kasha KJ. 1997. Regions of the genome that affect grain and malt quality in a North American two-row barley cross. Crop Sci. 37: 544-554.

Mayo O. 2004. Interaction and quantitative trait loci. Aust. J. Exp. Agric. 44: 1135-1140.

Mickelson S, See D, Meyer FD, Garner JP, Foster CR, Blake TK, Fischer AM. 2003. Mapping of QTL associated with nitrogen storage and remobilization in barley (Hordeum vulgare L.) leaves. J. Exp. Bot. 54: 801-812.

Peighambari SA, Yazdi Samadi B, Nabipour A, Charmet G, Sarrafi A. 2005. QTL analysis for agronomic traits in barley doubled haploids population grown in Iran. Plant Sci. 169: 1008-1013.

Schmitt MR, Budde AD. 2007. Improved methods for high throughput extraction and assay of green barley malt proteinase activity facilitate examination of proteinase activity across large-scale barley populations. Cereal Chemistry 84: 313-319.

See DR, Kanazin V, Kephart K, Blake TK. 2002. Mapping genes controlling variation in barley grai protein concentration. Crop Sci. 42:680-685. American barley germplasm. Theor. Appl. Genet. 87: 392-401.

Siyahsar BA, Narouei M. 2010. Mapping QTLs of physiological traits associated with salt tolerance in 'Steptoe' $\times$ 'Morex' doubled haploid lines of barley at seedling stage. Journal of Food, Agriculture Environment, 8: 751-759.

Singh M, Ceccarelli S, Hamblin J. 1993. Estimation of heritability from varietal triats data. Theor. Appl Genet. 86: 437-441.

Stuber CW, Polaco M, Senior ML. 1999. Synergy of empirical breeding marker assisted selection and genomics to increase crop yield potential. Crop Sci. 39: 1571-1583.

Taleei, A, Siyahsar BA, Peighambari SA. 2009. QTL Mapping for Forage Quality-Related Traits in Barley. Springer, CCIS 57: 53-62.

Therrien MC. 2003. Heritability estimates for forage quality in barley. Barley Genetics Newsletter 33: 16-17.

Wang S, Basten CJ, Zeng ZB. 2007. Windows QTL cartographer 2.5. Department of Statistics, North Carolina State University, Raleigh, NC.

Zeng ZB. 1994. Precision mapping of quantitative trait loci. Genetics. 136: 14 .. 